\title{
Kontrol Bandwidth Dinamis Berbasis Algoritma Logika Fuzzy pada Jaringan Wireless Ad-Hoc
}

\author{
Yedidio Purwodwiyogo ${ }^{\mathrm{a}}$, Alif Subardono ${ }^{\mathrm{b}}$ \\ a Departemen Teknik Elektro dan Informatika, Sekolah Vokasi, Universitas Teknologi Jaringan, yedidio9932@ gmail.com \\ ${ }^{\mathrm{b}}$ Departemen Teknik Elektro dan Informatika, Sekolah Vokasi, Universitas Teknologi Jaringan, masalif@gmail.com
}

\begin{abstract}
Ad-Hoc network is a wireless network consisting of a collection of nodes that are connected spontaneously and dynamically. With the character of the Ad-Hoc network, this network is often used in the development of IoT devices (Internet of Things) or emergency conditions. But in the implementation of the Ad-Hoc network there are challenges that need to be addressed, one of which is the very limited bandwidth that can be provide. The existence of these things will lead to new problems, when network traffic is very busy, it will reduce the fairness level of bandwidth distribution. Therefore, the implementation of fuzzy logic is proposed as a reliable decision maker in managing bandwidth. From the results found in this study prove that the results of the obtained throughput performance is not found to be a significant increase, but the jitter and packet loss produces a better value than when the bandwidth management system is applied.
\end{abstract}

Keywords: Bandwidth, Fuzzy logic, Ad-Hoc

\begin{abstract}
Abstrak
Jaringan Ad-Hoc adalah jaringan wireless yang terdiri dari kumpulan node yang terhubung secara spontan dan bersifat dinamik. Dengan karakter jaringan $A d-H o c$ tersebut, jaringan ini sering digunakan pada pengembangan perangkat IoT (Internet of Things) hingga kondisi darurat. Namun dalam implementasi jaringan Ad-Hoc terdapat tantangan yang perlu dihadapi, salah satunya adalah lebar bandwidth yang sangat terbatas. Adanya hal tersebut akan mengakibatkan permasalahan baru, ketika traffic jaringan sangat sibuk akan berkurangnya tingkat fairness pembagian bandwidth. Maka dari itu diajukan implementasi logika fuzzy sebagai penentu keputusan yang handal dalam memanajemen bandwidth. Dari hasil yang didapati pada penelitian ini membuktikan bahwa hasil performa throughput yang diperoleh tidak didapati peningkatan yang signifikan, namun pada nilai jitter dan nilai packet loss menghasilkan nilai yang lebih baik dari ketika sistem manajemen bandwidth diterapkan.
\end{abstract}

Kata kunci: Bandwidth, Logika Fuzzy, Ad-Hoc

(C) 2018 Jurnal RESTI

\section{Pendahuluan}

Jaringan Ad-Hoc adalah jaringan wireless yang terdiri dari kumpulan mobile node yang bersifat dinamik dan spontan. Jaringan ini terhubung antar satu node dengan node lain tanpa adanya konfigurasi awal atau kontrol tersentral. Sebagai hasil dari tipe karakteristik jaringan ini, terdapat peramasalahan yang akan dihadapi, salah satu dari permasalah tersebut adalah ketersediaan bandwidth yang terbatas. Dari permasalah tersebut tingkat fairness pada jaringan Ad-Hoc ini ditakutkan akan menurun ketika sedang pada kondisi trafik yang sibuk. Hal tersebut juga didukung dengan adanya paket jaringan sebagai mana yang diusulkan sebelumnya, User Datagram Protocol (UDP) yang sering digunakan akan memastikan layanan yang ada pada jaringan pada komunikasi jaringan. Yang mana paket UDP tidak tersebut terkirim dengan baik ke pengguna layanan terdapat fungsi flow bandwidth control, sehingga dari jaringan.

sisi pengirim akan mengirimkan paket UDP sebanyak

mungkin tanpa mengetahui kondisi yang terjadi pada jaringan tersebut.

Dalam memberikan layanan jaringan yang baik dibutuhkan manajemen kualitas jaringan yang sesuai dengan kebutuhan layanan yang diaplikasikan pada jaringan tersebut. Maka dari itu dibutuhkan suatu aturan dalam manajemen jaringan yang dapat menjamin tersedianya layanan tersebut. Seperti membagi lebar bandwidth untuk setiap layanan yang disediakan serta memberikan skala prioritas untuk layanan tersebut. Dengan penerapan manajemen

Diterima Redaksi : 25-09-2018 | Selesai Revisi : 16-11-2018 | Diterbitkan Online : 16-12-2018 
Manajemen lebar bandwidth dapat menjadi jalan keluar sejumlah penelitian mengenai strategi manajemen atas permasalahan ketersediaan yang terbatas. Namun bandwidth yang dinamis menggunakan logika fuzzy dibandingkan memberikan lebar bandwidth untuk untuk mengoptimalkan penggunaan sumber daya setiap layanan secara tetap, akan lebih baik ketika lebar bandwidth yang digunakan.

bandwidth secara dinamis dapat berubah sesuai kondisi trafik [3] yang berlangsung pada jaringan Ad-Hoc. Tentunya dengan berubahnya lebar bandwidth ini juga harus memastikan bahwa layanan lain tidak terganggu ketersediaannya. Sebagai alternatif dalam manajemen bandwidth secara dinamis diperlukan suatu kontrol yang dapat menetukan lebar bandwidth yang diperlukan. Terdapat berbagai cara dalam menerapkan konsep manajemen bandwidth secara dinamis, sebagai contohnya dapat menerapkan teori kecerdasan buatan. Untuk mendukung usulan alternatif tersebut teori kecerdasan buatan perlu diaplikasikan untuk menetukan output yang diberikan dalam kondisi tertentu secara langsung, yang mana teori logika fuzzy dapat dijadikan sebagai landasan menerapkan manajemen bandwidth secara dinamis.

Logika fuzzy sendiri merupakan suatu metode dalam bandwidth; Early Request First Strategy (ERFS) yang menentukan nilai yang berada pada titik abu-abu merupakan konsep sederhana dari first-come-first-serve (nilainya berada pada antara $0-1$ ), yang mana logika memastikan tercapainya fairness, namun terdapat fuzzy ini menggantikan kebenaran boolean dengan peningkatan kemungkinan terjadinya blocking, Short tingkat kebenaran. Dalam penerapannya, logika fuzzy Request First Strategy (SRFS) mengutamakan layanan pada sistem manajemen kualitas jaringan akan terpendek pada buffer untuk diproses, hal ini akan mengelola lebar bandwidth disesuaikan dengan kondisi menyebabkan layanan dengan waktu terlama dan kebutuhan jaringan pada saat itu juga. Hal tersebut interval waktu shareable slot yang digunakan oleh dapat terjadi ketika parameter kualitas jaringan LTBS akan semakin panjang. Konsekuensinya adalah dijadikan tolak ukur dalam penentuan keputusan. Oleh permintaan RTBS akan terabaikan dan permintaan karena itu pada penelitian ini akan menerapkan logika yang lebih dulu datang akan ditunda telebih dahulu fuzzy pada jaringan Ad-Hoc, dengan harapan dapat yang menyebabkan berkurangnya fairness, Adaptive meningkatkan fairness pada jaringan Ad-Hoc.

Terdapat juga rumusan masalah yang ditentukan pada penelitian ini yaitu; Apakah dengan implementasi logika fuzzy dapat meningkatkan throughput dan fairness pada jaringan Ad-Hoc? Serta bagaimana perbandingan performa logika fuzzy dengan sistem manajemen bandwidth konvensional pada jaringan $A d$ Hoc?

Dari latar belakang yang telah disebutkan, penelitian ini peningkatan . Kemungkinan blocking SRFS akan ditujukan untuk menerapkan logika fuzzy pada digunakan, selain itu akan menggunakan ERFS untuk manajemen bandwidth secara dinamis pada jaringan meningkatkan fairness jaringan, Enhanced FESS Ad-Hoc, mengetahui perbandingan kinerja logika fuzzy (EFESS) pada strategi ini menggunakan dua strategi dengan sistem manajemen bandwidth yang secara bersamaan. Ketika kapasitas shareable konvensional dan juga meningkatkan throughput dan bandwidth dapat mengatasi RTBS trafik, ERFS dapat fairness pada pada jaringan Ad-Hoc.

\section{Tinjauan Pustaka}

Logika Fuzzy merupakan salah satu kecerdasan buatan paket dengan strategi ERFS dan borrowed slot yang merupakan bukan hal baru dalam memberikan melayani paket dengan waktu lanyanan terpendek. keputusan terhadapat suatu kondisi tertentu. Hal ini Hasil yang didapat dari kelima strategi ini adalah dapat memberikan hasil yang lebih optimal dalam suatu dengan mengaplikasikan logika fuzzy dapat proses yang sedang berjalan, dikarenakan sumber daya memastikan utilisasi bandwidth dan fairness yang yang digunakan pada suatu proses tersebut digunakan tinggi dan kemungkinan blocking yang rendah [2]. sesuai dengan kebutuhan pada kondisi yang memiliki sifat kedinamisan yang tinggi. Maka dari itu terdapat
Jurnal RESTI (Rekayasa Sistem dan Teknologi Informasi) Vol. 2 No. 3 (2018) 728 - 735 
Dalam pengujian strategi sistem manajemen bandwidth meneruskan paketnya dengan melakukan broadcast ke dinamis, terdapat pula strategi dengan menganalisis tetangganya. Yang mana paket tersebut akan tersimpan buffer pada trafik jaringan dengan single output link. sementara di buffer untuk diterukan ke node tujuan. Konsep utama dalam implemetasi logika fuzzy pada Pada buffer harus ditentukan nilainya untuk dapat strategi ini adalah dengan dengan membandingkan menetukan network delay dan throughput. Nilai price buffer dari sumber yang berbeda, yang kemudian dari dari suatu router ditentukan dari besaran antrian, yang nilai yang didapat akan menjadi tolak ukur dalam mana besaran antrian tersebut menjelaskan perbedaan menetukan buffer dari sumber mana yang perlu antara network load dan wireless bandwidth. mendapat lebar bandwidth lebih. Di waktu yang sama Konsekuensinya adalah nilai price akan terus pada melayani buffer tersebut, dilakukan juga ditambahkan hingga utilisasi dari router lebih besar dari penghitungan ulang terhadap nilai lebar bandwidth. Hal threshold, selain itu nilai price akan dikurangikan. Dari tersebut dilakukan secara berkala dalam interval waktu konsep tersebut Fuzzy Source Controller (FSC) yang tertentu. Dari hasil yang didapat pada penelitian dengan digunakan untuk menetukan source rate pada jaringan strategi ini dapat disimpulakan bahwa mekanisme Ad Hoc, disimpulkan bekerja lebih baik pada jaringan manajemen bandwidth ini meningkatkan performa wireless multi-hop. Hasil yang diperoleh pada skema buffered network dan memberikan hasil QoS yang lebih ini menghasilkan respon yang baik dari pemakaian baik dari alternatif yang ditawarkan ketika sumber buffer dan transmission rate, sehingga diperoleh trafik memiliki intensitas perubahan yang tinggi pada utilisasi yang lebih baik [4].

interval waktu yang pendek [3].

Penelitian lain dilakukan pada jaringan yang dibagi 3. Metodologi Penelitian

menjadi beberapa jaringan virtual, yang ditujukan untuk memungkinkan pengguna jaringan dapat mengelompokkan trafik. Dynamically Adaptive Virtual Network for a Customized Internet (DaVinci) merupakan suatu teknik yang memungkinkan terbentuknya beberapa virtual network dengan membagi setiap node fisik dan link fisik menjadi beberapa node virtual dan link virtual. Masalah yang dijumpai pada DaVinci, utilisasi dari setiap link virtual yang telah terbentuk tidak semua terpakai secara maksimal. Logika fuzzy sendiri membutuhkan 3 variabel sebagai input yaitu; rata-rata utilisasi link virtual, rata-rata panjang antrian dan rata-rata paket delay. Dari setiap variabel tersebut dibuat fungsi keanggotaan yang didaftarkan dengan nama $L O W$, $M E D I U M$ dan $H I G H$. Pada percobaannya dibuat 2 virtual dengan kondisi variabel input fuzzy yang berbeda. Kemudian dari input ynag masuk akan bandingkan dengan rule yang telah dibuat. Pada dasarnya rule tersebut memastikan ketika utilisasi pada link virtual pada kondisi $H I G H$ serta delay atau panjang antrian tidak sama dengan $L O W$ maka sisa bandwidth pada link virtual lain akan akan dipindahkan ke link virtual yang membutuhkan. Hasil dari uji coba ini adalah rata-rata delay yang dihasilkan lebih kecil dari pada DaVinci yang tidak menggunakan fuzzy, begitu pula pada nilai utilisasi yang diperoleh lebih besar [1].

Dalam penerapan teori kecerdasan buatan pada manajemen bandwidth, strategi lain diajukan ketika diimplementasikan pada jaringan Ad Hoc. Strategi ini menggunakan variabel price yang diperoleh dari pesan ACK yang dikirimkan oleh node destination ke node sender. Variabel price tersebut akan digunakan oleh node sender untuk menentukan lebar bandwidth yang dibutuhkan. Skema kontrol ini dinilai cukup adil dalam memungkinkan suatu flow untuk menambah nilai price

3.1 Perancangan topologi

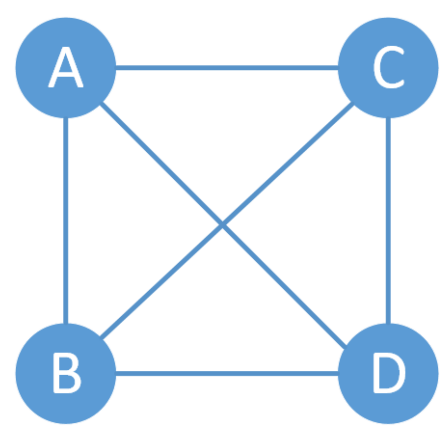

Gambar 1. Topologi jaringan Ad-Hoc

Topologi jaringan dalam proyek akhir ini dirancang untuk dapat menjalankan 3 skenario yaitu: tanpa menerapkan manajemen bandwidth; manajemen bandwidth dengan memberikan nilai lebar bandwidth yang tetap; manajemen bandwidth dengan menerapkan logika fuzzy sebagai kontrol lebar bandwidth. Topologi ini terdiri atas 4 buah Raspberry Pi 3 Model B yang terhubung secara wireless dengan mode Ad-Hoc. Sistem routing pada jaringan ini tidak diterapkan, sehingga sifat jaringan ini adalah peer-to-peer.

Dalam menentukan alamat IP, setiap node berada pada satu jaringan yang sama yaitu 10.0.0.0/24. Untuk lebih jelasnya dapat dilihat pada Tabel 1 .

Tabel 1.Tabel Software dan Hardware Pendukung

\begin{tabular}{ll}
\hline Nama Perangkat & Alamat IP \\
\hline Node A & $10.0 .0 .1 / 24$ \\
Node B & $10.0 .0 .1 / 24$ \\
Node C & $10.0 .0 .1 / 24$ \\
Node D & $10.0 .0 .1 / 24$ \\
\hline
\end{tabular}
pada route yang dipakai. Pada jaringan wireless node 


\subsection{Metode logika fuzzy}

Berikut merupakan bagian-bagian yang ada pada sistem logika fuzzy :

\section{Pembentukan variabel}

Veriabel input yaitu besar packet TCP, yang kemudian akan menghasilkan nilai $P$ dari hasil perhitungan sebagai berikut:

$$
P=1-\frac{\text { besar packet } T C P}{\text { kapasitas buffer }}
$$

Dari hasil perhitungan tersebut akan varibel $P$ selalu perlu diturunkan. Untuk rule 2 dan rule 3 juga memiliki menghasilkan nilai dengan interval $[-1,1]$. Dengan penjelasan yang kurang lebih sama.

begitu [-1,1] dapat dikatakan merupakan semesta pembicaraan dari $P$.

\section{Fuzzyfikasi}

Pada himpunan fuzzy ini variabel $P$ memiliki 3 himpunan fuzzy yaitu sangat negatif, nol dan sangat positif. Himpunan fuzzy untuk variabel $P$ ditunjukan dalam gambar 2 .

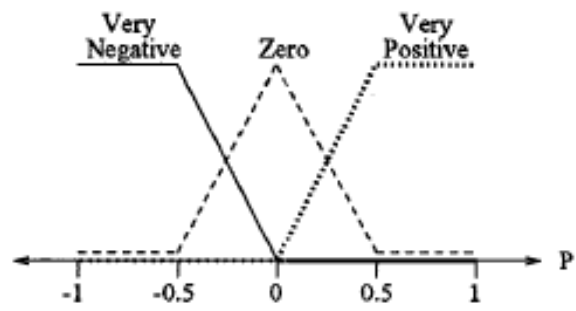

Gambar 2. Himpunan fuzzy untuk variabel $P$

dibentuk. Pada cara kerja dari inference engine ini dibutuhkan fuzzy rule untuk menalarkan keluaran yang diharapkan. Fuzzy rule tersebut ditulis sebagai berikut: $\mathrm{R} 1:$ Jika $P$ very negative, maka $\alpha$ small R2: Jika $P$ mendekati zero, maka $\alpha$ medium R3: Jika $P$ very positive, maka $\alpha$ large

Dari rule yang telah ditentukan dapat dijelaskan dengan contoh sebagai berikut. Jika $P$ berada pada domain very negative maka konten 2 melebihi dari konten 1, yang mengimplikasikan kebutuhan untuk meningkatkan layanan pada konten 2 dengan kata lain nilai dari $\alpha$ 4. Defuzzyfikasi

Pada program logika fuzzy ini menerapkan metode Sugeno yang mana menghasilkan output berupa konstanta. Maka dari itu pada variable $\alpha$ dengan semesta pembicaraan dari nilai 0 sampai dengan 40 , yang mana nilai tersebut merupakan nilai bandwidth yang ditentukan berdasarakan hasil performa throughput yang konsisten. Variable $\alpha$ juga memiliki 3 himpunan yaitu small, medium dan large dimana dalam pembagian domain untuk setiap himpunan diserakan pada library Scikit-Fuzzy.

Nilai keluaran dari hasil defuzzyfikasi akan dijadikan untuk menentukan besaran bandwidth yang diberikan pada trafik UDP. Hal ini dilakukan karena pada protokol UDP tidak terdapat fungsi flow control, sehingga mangakibatkan trafik UDP lebih mendominasi dari pada trafik TCP

\subsection{Proses pengambilan data}

Pada himpunan fuzzy sangat negatif memiliki domain [$1,0]$ dengan derajat keanggotaan tertinggi $(=1)$ terletak pada nilai antara $-1-(-0,5)$ dengan persamaan :

$$
f_{V . N e g .}[P]=\left\{\begin{array}{c}
1 ; \\
(0-P) /(0-(-0,5)) \\
0 ;
\end{array}\right.
$$

Dalam pengambilan data, dibagi menjadi dua bagian yaitu; dengan menggunakan software Iperf3 dan DITG. Dalam penelitian ini kedua software tersebut akan membuat trafik UDP dan TCP yang mana proses tersebut akan berlangsung selama 60 detik. Selama kurun waktu tersebut akan terdapat tiga trafik dalam Pada himpunan fuzzy nol memiliki domain [-0,5, -0,5] jaringan Ad-Hoc yang telah dirancang, yaitu; UDP, dengan derajat keanggotaan tertinggi $(=1)$ terletak pada TCP1 dan TCP2. Ketiga trafik tersebut juga berjalan nilai 0 dengan persamaan :

$$
f_{\text {Zero }}[P]=\left\{\begin{array}{c}
0 \\
(P-(-0,5)) /(0-(-0,5)) \\
(0,5-P) /(0,5-0)
\end{array}\right.
$$

Pada himpunan fuzzy sangat positif memiliki domain berikut:

$[0,1]$ dengan derajat keanggotaan tertinggi $(=1)$ terletak pada nilai antara $0,5-1$ dengan persamaan :

$$
f_{\text {V.Pos. }}[P]=\left\{\begin{array}{c}
0 ; \\
(P-0) /(0,5-0) ; \\
1 ;
\end{array}\right.
$$

\section{Inference Engine} dalam interval waktu yang berbeda dan waktu mulai yang berbeda, upaya ini dilakukan untuk dapat melihat bagaimana karakter kerja dan sifat kedinamisan dari protokol UDP dan TCP ketika dikirimkan. Secara detail dalam proses pengambilan data akan dijelaskan sebagai

\section{a. Iperf3}

Iperf3 merupakan salah satu software yang ditujukan untuk membuat trafik dalam suatu jaringan. Hal ini ditujukan untuk memperoleh data yang kemudian dapat digunakan untuk menyatakan kemampuan dari jaringan yang diuji. Kelebihan dari Iperf3 ini dapat menampilkan kemampuan jaringan dalam interval waktu yang dibutuhkan, untuk kasus ini interval waktu ditentukan setiap satu detik. Proses trasnmisi paket dalam jaringan ini akan terdapat tiga node yang 
menjadi server (Node A, Node B dan Node C) dan satu manajemen bandwidth dengan menerapkan logika fuzzy node yang menjadi client (Node D). Tugas dari node sebagai kontrol lebar bandwidth.

client ini akan mengirimkan paket UDP ke node server selama 60 detik dengan ukuran paket sebesar 8 Kbit dan mengirimkan paket TCP ke node server selama 25 detik dengan ukuran paket sebesar 128 Kbit, dimana ukuran paket yang disebutkan merupakan nilai default. Dalam kurun waktu 60 detik akan dijalankan terlebih dahulu trafik UDP, kemudian setelah 10 detik berjalan akan ditambahkan trafik TCP1 dan 25 detik berjalan trafik TCP2 ditambahkan ke dalam jaringan. Berikut merupakan contoh perintah untuk trafik UDP pada sisi client:

iperf3 - c <ip_server> - $t<$ waktu_traffic $>-\mathrm{u}-\mathrm{b} 0$

dan berikut merupakan perintah dari trafik TCP:

iperf3 - c <ip_server> - $t$ <waktu_traffic>

pada paket UDP “-b 0" ditujukan agar paket UDP tidak dibatasi oleh bandwidth yang secara default bernilai 1 Mbps.

\section{b. D-ITG}

D-ITG juga merupakan software traffic generator yang memiliki flexibilitas yang lebih dari pada iperf3, namun yang membedakan adalah pada D-ITG tidak dapat menampikan hasil setiap interval waktu dan hanya menampilkan rata-rata dari trafik yang dibuat. Secara garis besar metode pembuatan trafik pada jaringa $A d$ - Pada bagian ini dibagi menjadi dua bagian, antara lain Hoc ini identik dengan apa yang ada pada Iperf3, yaitu yaitu; hasil data yang diperoleh dari software traffic terdapat tiga trafik UDP, TCP1 dan TCP2 yang generator Iperf3 dan D-ITG. Pada Iperf3 data berupa dijalankan pada waktu interval dan waktu mulai yang hasil throughput berdasarkan interval 1 detik, berbeda. Sama juga dengan Iperf3, D-ITG juga sedangkan pada D-ITG hasil yang data yang diperoleh membutuhkan node yang menjadi client dan server. berupa nilai rata-rata jitter, packet loss dan throughput Berikut merupakan contoh perintah pada sisi client dari 4 kali pengambilan data. untuk trafik UDP:

./ITGSend -T UDP $-\mathrm{a}$ <ip_server>-c $8192-\mathrm{C} 100000$ $-\mathrm{t} 60000-1$ sender.log $-\mathrm{x}$ receiver.log

Dan berikut merupakan contoh perintah untuk trafik TCP:

./ITGSend -T TCP -a <ip_server> -c 131072 -C $100000-\mathrm{t} 25000-1$ sender.log $-\mathrm{x}$ receiver.log

Perintah diatas ditujukan untuk membuat trafik UDP dengan besar paket 8 Kbit dan banyak paket per detik sebesar 100000 pps selama 60 detik, begitu pula pada trafik TCP dengan besar paket $128 \mathrm{Kbit}$ dan banyak paket perdetik sebesar 100000 pps selama 25 detik.

4.1 Hasil Pengujian Iperf3

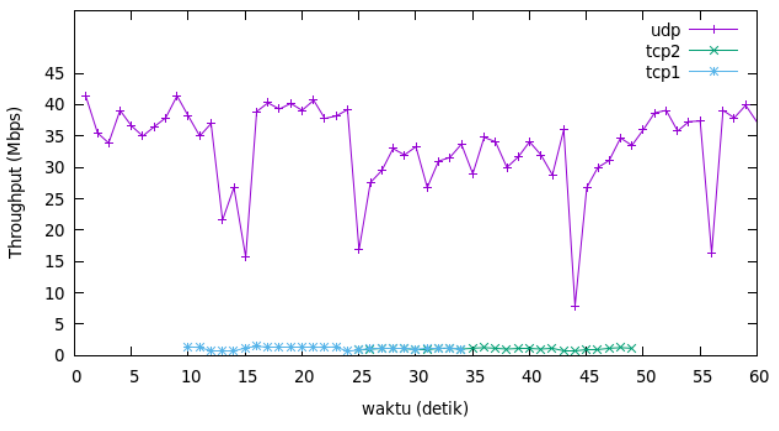

Gambar 3. Hasil throughput tanpa manajemen bandwidth

\subsection{Detail skenario}

Dari hasil pengujian tanpa adanya manajemen bandwidth, dapat dikatakan bahwa pada hasil trafik Pada penelitian ini, untuk dapat mengambil kesimpulan UDP sangat mendominasi dibandingkan dengan trafik dari menerapkan logika fuzzy pada manajemen TCP1 dan TCP2. Hal ini disebabkan pada protokol bandwidth terdapat tiga skenario yang diusulkan. Tiga UDP tidak terdapat adanya fungsi flow control yang skenario tersebut merupakan; tanpa menerapkan pada akhirnya mengakibatkan paket UDP akan manajemen bandwidth, manajemen bandwidth dengan dikirimkan tanpa melihat kondisi trafik pada jaringan memberikan nilai lebar bandwidth yang tetap, yang digunakan. Nilai throughput yang diperoleh trafik 
UDP ini tidak begitu stabil dengan ditandainya nilai dengan yang dihasilkan pada skenario tanpa yang bersifat fluktiatif, dengan nilai tertingginya menerapkan manajemen bandwidth. mampu sampai lebih dari 40 Mbps dan nilai terendah hingga 10 Mbps pada detik ke-44. Dari hasil trafik TCP1 dan TCP2 nilai throughput yang diperoleh cukup stabil di nilai kurang dari 3 Mbps.

Sebagai jalan keluar dari permasalahan yang terjadi pada skenario sebelumnya, dilakukan penambahan pengembangan terhadap script logika fuzzy. Hal tersebut dilakukan dengan cara memfilter paket yang Hasil dari pada skenario penerapan manajemen dijadikan nilai masukan pada logika fuzzy. Pada bandwidth konvensional untuk membatasi throughput Gambar 4.4 merupakan hasil yang diperoleh setelah dari trafik UDP agar tidak lebih dari $13.3 \mathrm{Mbps}$, memastikan hanya paket dengan ukuran lebih dari 1500 membuktikan bagaimana kerja fungsi flow control bit saja yang menjadi nilai inputnya. Dari hasil yang yang ada pada ptotokol TCP. Trafik TCP1 dan TCP2 diperoleh ketika trafik TCP1 masuk, dengan segera pada detik ke-25 yang mana trafik TCP2 mulai masuk trafik UDP diturunkan lebar bandwidthnya. Hal ini pada jaringan, trafik TCP1 secara langsung menurukan terjadi dikarenakan hasil dari memfilter paket yang besar bitrate agar pada trafik TCP2 mendapatkan dijadikan nilai masukan, berbeda dengan program throughput yang dapat dikatakan cukup adil dengan sebelumnya yang membaca secara keseluruhan varisasi trafik TCP1. Kemudian pada detik ke-35 dimana trafik dari besar paket yang diterima. Dengan stabilnya besar TCP1 telah selesai trafik TCP2 terdapat kenaikan nilai bandwidth untuk trafik UDP, maka throughput yang bitrate yang sama dengan trafik TCP1 ketika hanya dihasilkan pada trafik TCP1 dapat meningkat. Ketika terdapat satu trafik protokol tcp pada jaringan.

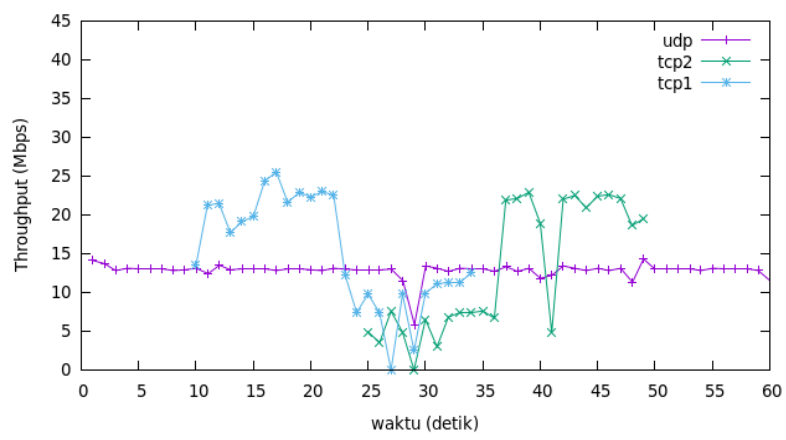
trafik TCP2 masuk ke jaringan terdapat lonjakan dan turunan throughput pada setiap trafik, dilanjukan dengan meningkatnya throughput trafik TCP2 dan kestabilan throughput UDP setelah trafik TCP1 berakhir. Namun terdapat kelemahan pada sistem ini yaitu ketika trafik TCP2 berakhir, throughput trafik UDP tidak mengalami peningkatan. Hal ini dikarnakan sistem filter pada nilai masukan yang mencegah paket dengan ukuran kecil untuk diproses oleh logika fuzzy. Dengan ini lebar bandwidth pada trafik UDP tidak dapat ditingkatkan.

Gambar 4. Hasil throughput dengan manajemen bandwidth konvesional
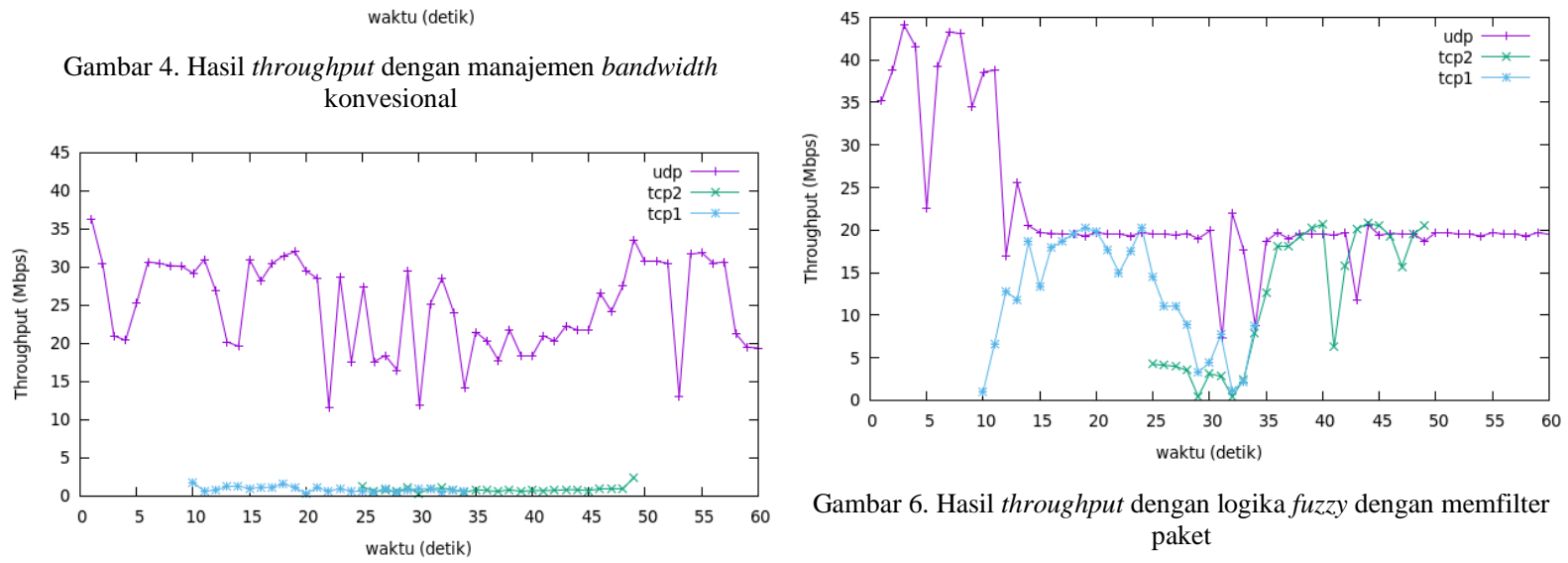

Gambar 6. Hasil throughput dengan logika fuzzy dengan memfilter paket

Gambar 5. Hasil throughput dengan logika fuzzy

\subsection{Hasil Pengujian D-ITG}

Pada hasil yang diperoleh pada skenario yang Hasil yang diperoleh pada uji coba dengan D-ITG ini, mengimplementasikan logika fuzzy sebagai manajemen terdapat 3 data yang dibahas. Data tersebut merupakan bandwidth, tingkat kestabilan nilai throughput yang data nilai rata-rata jitter, nilai rata-rata packet loss dan diperoleh dikatakan lebih buruk dari pada tanpa adanya nilai rata-rata throughput, yang mana dibuat manajemen bandwidth. Hal ini disebabkan adanya perbandingan antara skenario satu dengan yang lain. antrian dalam membaca nilai lebar paket tcp, yang mana kondisi trafik pada jaringan tidak sesuai dengan keluaran yang dihasilkan. Penyebab utamanya adalah waktu yang cukup lama dalam mengubah rule pada program Tcconfig. Maka dari itu throughput pada trafik a. Hasil jitter

Dari hasil yang diperoleh pada trafik UDP untuk setiap skenario, nilai jitter termasuk dalam kategori bagus dengan nilai terendah sebesar 3,2 ms dan nilai terbesar 8 ms. Pada trafik TCP1 dan TCP2 memperlihatkan bahwa nilai jitter untuk skenario tanpa manajemen

Jurnal RESTI (Rekayasa Sistem dan Teknologi Informasi) Vol. 2 No. 3 (2018) 728 - 735 
bandwidth menghasilkan nilai yang cukup tinggi yaitu nilai yang lebih baik dibandingkan dengan skenario 2 . $84 \mathrm{~ms}$ dan 96,5 ms, hasil tersebut termasuk dalam Pada penerapan logika fuzzy dapat dikatakan cukup kategori sedang dan dapat dikatakan bahwa terjadi berhasil dalam memastikan tidak adanya packet loss antrian paket yang cukup tinggi.

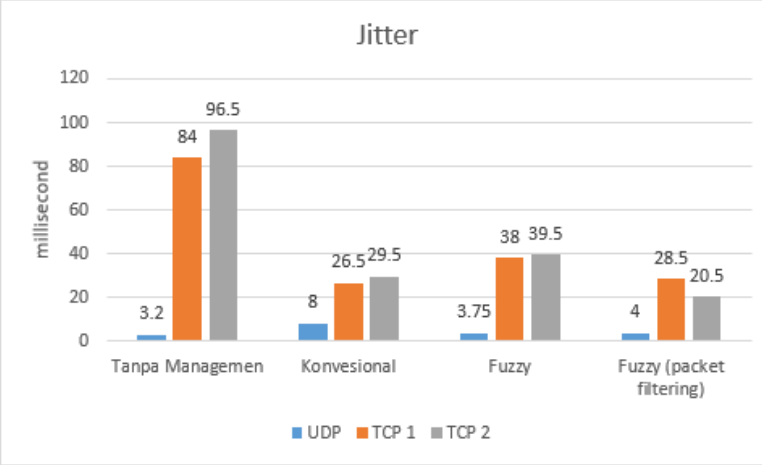

Gambar 7. Perbandingan nilai rata-rata jitter

Skenario dengan memanajemen bandwidth secara konvensional membuktikan bawah dengan menetapkan lebar bandwidth pada trafik UDP mampu untuk mengurangi terjadinya antrian paket yang ditandai dengan menurunnya nilai jitter pada trafik TCP1 dan TCP2 yang cukup signifikan. Pada penerapan logika fuzzy juga memberikan nilai yang baik walaupun terdapat kenaikan yang dihasilkan sebesar kurang lebih 10 ms dari pada skenario sebelumnya dan menghasilkan nilai throughput yang terbilang rendah, hasil throughput dapat dilihat pada Gambar 9. Pada bagian fuzzy dan filtrasi paket ini dapat dikatakan menghasilkan nilai jitter yang lebih baik dari pada skenario lainnya, hal tersebut ditandainya nilai jitter yang lebih rendah.

\section{b. Hasil packet loss}

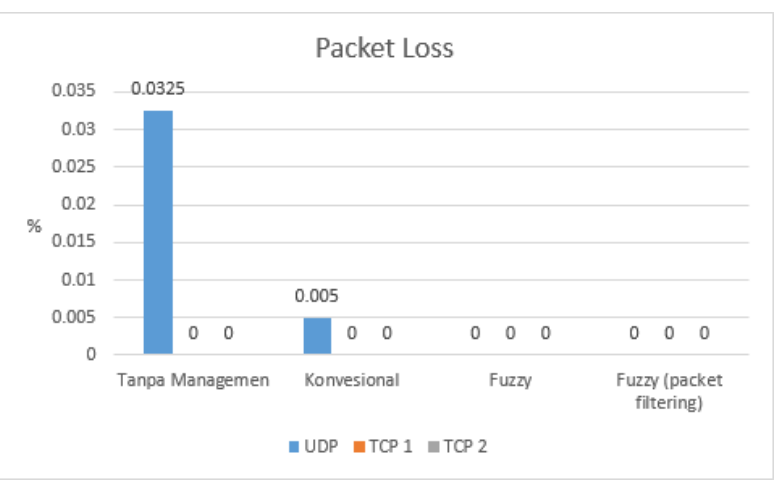

Gambar 8. Perbandingan nilai rata-rata packet loss

Pada Gambar 8 menjelaskan bahwa pada dasarnya nilai packet loss dari semua skenario terbilang sangat baik. Hal ini didukung dengan topologi jaringan Ad-Hoc yang memungkinkan setiap node dapat berkomunikasi dengan node lainya dengan cara peer-to-peer, sehingga meminimalisir terjadingan packet loss. Untuk skenario tanpa manajemen bandwidth sekalipun menghasilkan throughput yang tinggi dan lebih dominan dari trafik lainnya, hal tersebut tidak memastikan menghasilkan

\section{c. Hasil throughput}

Hasil throughput dari D-ITG memiliki karakteristik yang sama dengan hasil yang diperoleh dari Iperf3. Dimana pada penerapan tanpa adanya manajemen bandwidth hasil performa throughput dari trafik UDP sangat mendominasi, sehingga menurunkan performa throughput dari trafik TCP1 dan TCP2. Pada penerapan manajemen bandwidth konvensional terlihat bahwa trafik UDP diberi limitasi yang ditandai dengan besar throughput yang tidak melebihi 13,3 Mbps. Begitu pula dengan hasil yang diperoleh pada trafik TCP1 dan TCP2 dimana kedua trafik dapat membagi beban trafik sendiri sehingga dapatkan hasil performa throughput yang tidak terlalu berbeda. Penerapan logika fuzzy sendiri kurang begitu terlihat perbedaan dengan hasil yang diperoleh tanpa menerapkan manajemen bandwidth dimana masih terlihat mendominasinya trafik UDP dari pada trafik lain. Hal tersebut disebabkan adanya keterlambatan program logika fuzzy dalam membaca kondisi trafik ketika trafik TCP masuk. Ketika ditambahkan baris perintah untuk memfilter paket dengan ukuran lebih dari 1500 bit pada script program logika fuzzy, terlihat bahwa terdapat peningkatan hasil throughput pada trafik TCP1 dan TCP2. Bahkan total throughput yang diperoleh lebih tinggi dari pada scenari lain. Dengan ini setelah melakukan perbaikkan pada script program logika fuzzy didapati hasil yang lebih baik. Namun pada penerapan memfilter besar paket yang diproses akan berdampak ketika hanya trafik UDP yang ada pada jaringan, dimana lebar bandwidth pada trafik tersebut tidak dapat diperbesar.

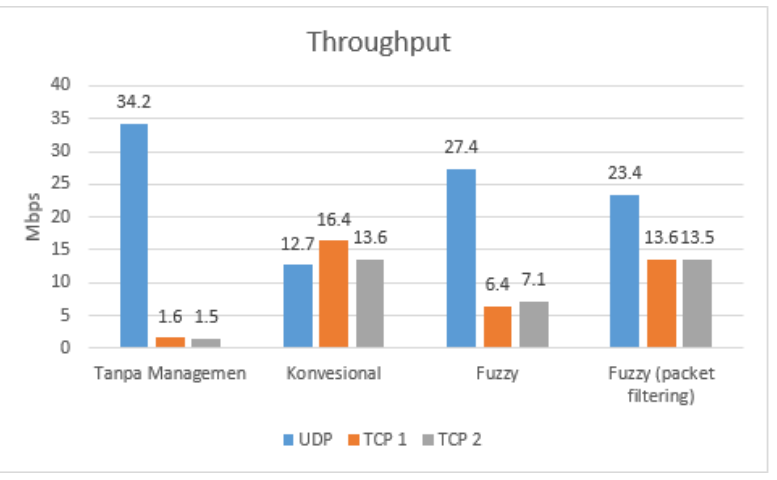

Gambar 9. Perbandingan nilai rata-rata throughput

\section{Kesimpulan}

\subsection{Simpulan}

Berdasarkan hasil analisis pengujian kontrol bandwidth dinamis berbasis algoritma logika fuzzy pada jaringan wireless ad-hoc, maka dapat diambil kesimpulan sebagai berikut. 
1. Penerapan logika fuzzy sebagai system manajemen 1. Menerapkan manajemen bandwidth dinamis bandwidth dinamis menghasilkan performa throughput yang hampir tidak ada bedanya dengan kondisi tanpa menambahkan manajemen bandwidth pada jaringan, yang mana didapati trafik UDP yang sangat mendominasi dari trafik TCP.

2. Hasil perbandingan performa QoS pada setiap skenario yang diperoleh, dapat dikatakan bahwa dengan menerapakan sistem manajemen bandwidth konvensional atau manajemen bandwidth dinamis dengan logika fuzzy menghasilkan nilai packet loss dan jitter yang lebih baik dari pada tanpa adanya sistem manajemen bandwidth.

\subsection{Saran} berbasis algoritma logika fuzzy pada jaringan AdHoc yang menerapkan system routing.

2. Sistem manajemen bandwidth dinamis berbasis algoritma logika fuzzy dipasangkan pada perangkat yang memiliki kemampuan proses yang lebih baik dari pada Raspberry Pi 3 Model b.

\section{Daftar Rujukan}

1] Asmuss, J., \& Lauks, G., 2013. A Fuzzy Logic Based Approach to Bandwidth Allocation in Network Virtualization. Science and Information Conference (hal. 7). London: Science and Information.

[2] Sheu, S. T., \& Chen, M. H., 1999. A Fuzzy Bandwidth Allocation Controller to Support Real-time Traffic over Wireless Network. IEEE Conference (hal. 5). Tamsui: IEEE.

Berikut adalah saran yang dapat digunakan untuk mengembangkan penelitian lebih lanjut terkait manajemen bandwidth dinamis berbasis algoritma logika fuzzy.

[3] Slonowsky, D., Jiang, Q., \& Srinivasan, R., 2002. A Fuzzy Dynamic Bandwidth Re-Allocator. IEEE Canadian Conference (hal. 8). Toronto: IEEE Canadian.

[4] Yi, C., Hao, L., Ge, G., \& Ruimin, H., 2007. A Resource Allocation Control for Wireless Ad Hoc Networks. IEEE Conference (hal. 4). Wuhan: IEEE. 